Relations industrielles

Industrial Relations

\title{
Bruno, Robert, Steelworker Alley: How Class Works in Youngstown
}

\section{Jack Metzgar}

Volume 55, numéro 4, 2000

URI : https://id.erudit.org/iderudit/051359ar

DOI : https://doi.org/10.7202/051359ar

Aller au sommaire du numéro

Éditeur(s)

Département des relations industrielles de l'Université Laval

ISSN

0034-379X (imprimé)

1703-8138 (numérique)

Découvrir la revue

Citer ce compte rendu

Metzgar, J. (2000). Compte rendu de [Bruno, Robert, Steelworker Alley: How

Class Works in Youngstown]. Relations industrielles / Industrial Relations, 55(4),

775-776. https://doi.org/10.7202/051359ar

Tous droits réservés @ C Département des relations industrielles de l'Universite Laval, 2000
Ce document est protégé par la loi sur le droit d'auteur. L’utilisation des services d'Érudit (y compris la reproduction) est assujettie à sa politique d'utilisation que vous pouvez consulter en ligne.

https://apropos.erudit.org/fr/usagers/politique-dutilisation/ 
organizing tactics and are thus in a position to grow, and ultimately secure stronger contracts for their members.

Organizing Immigrants provides a timely and coherent analysis of the key issue facing North American unions, and of some of the strategies that will allow us to meet this challenge.

JoNATHAN EATON

Union of Needletrades, Industrial and Textile Employees

\section{Steelworker Alley: How Class Works in Youngstown}

by Robert BRUNO, Ithaca, N.Y.: ILR Press, 1999, 222 pp., ISBN 0-8014-

3439-4 (cloth) and ISBN 0-8014-8600-9 (paper).

Like me, Robert Bruno is a college professor who grew up in a steelworker family during the era of union power, 1942-1982. In graduate school he learned that by the mid-1950s, about the time he was born, steelworkers in the U.S. had become thoroughly "middle class." Bruno, however, could not "connect what I later knew about middleclass prosperity and values with the way my parents lived," nor could he reconcile the "dissonance I felt between accepted doctrine and my own experiences." Steelworker Alley presents his case that the accepted doctrine is wrong and that steelworkers then and now share a working-class identity.

Combining a neo-Marxist framework borrowed from Ira Katznelson with sophisticated social science methods, Bruno interviewed 75 retired steelworkers from the Youngstown, Ohio, area and analysed neighbourhood census data and historical archives for the industrial borough of Struthers, where he grew up. Among his interviewees were his father and mother and many of their friends, neighbours and workmates. What results is both a poignant portrait and a compelling analysis of steelworkers who are not now nor have they ever been "middle class."

To Canadians this may seem a trivial exercise, but in the U.S. we are generally not permitted to speak of a "working class." During the Cold War it was more than faintly disloyal to do so, while today it is still not permissible unless you can supply a one-sentence definition that is immediately acceptable to middleclass professionals whose own culture is deeply committed to the idea that everybody but the "rich" and "poor" is exactly like them, only less so. Bruno supplies no such definition. Instead, with the aid of his interviews, he systematically looks at the workplace, neighbourhood, consumer, and local political lives of his interviewees to reveal a culture that is palpably different from standard conceptions.

In the end, Bruno found a way of life utterly devoid of the kind of acquisitive individualism, personal ambition, statusconsciousness and achievement-orientation characteristic of middle-class life. "In Youngstown," he concludes, "the working class... valued cooperation, mutual aid, collective work, common needs, personal dignity, and equality of condition." Furthermore: "Neighbors were expected to be cognizant of each other and provide mutual support, usually without being asked. A selfish act of individualism was the inglorious badge of a "scab," and human freedom was defined less by willed decisions than it was by acting in ways that preserved the past for the next generation. What steelworkers expressed through their relationships was nothing less than a nonexploitive way to live" (p. 162).

Is this a romanticization? I don't think so, but that may depend on which romance you favour. The working class Bruno presents is no revolutionary vanguard, nor even a soft-spoken opponent of capitalism. But it has what Bruno 
calls an "us versus them mentality" that it freely exercises in the workplace, in (local) politics, and even in its consumption patterns, where trading favours among friends reduces dependence on the cash nexus.

Steelworker Alley is a good read, full of well-told stories drawn from the everyday lives of Youngstown retirees. These stories are not dramatic or emotionally stirring in themselves. What gives them their punch is the way Bruno uses them to illustrate his sense of "the authenticity of the working class." Alley's greatest strength is that it finds class consciousness in places where others have not looked - in the solidaristic ways workers interact with and feel about each other, not only in the mill but on bowling teams, in family crises, and on the Struthers City Council, which union steelworkers dominated for a quarter century.

But this wonderful intimacy also leads to the book's most important weakness. Bruno is so firmly focused on steelworkers' daily culture that he ignores the broader, more complex and contradictory culture of the working class as a whole. In the end, Steelworker Alley is a portrait of one occupational culture within the working class and does not really show "How Class Works in Youngstown."

Steel towns in postwar America were not typical of working-class community life precisely because they were so dominated by one occupational (and union) culture. In Struthers, for example, more than a quarter of the adult male population were steelworkers in the $1960 \mathrm{~s}$, and of those, 75 percent lived within a mile's walk of the mill. While Bruno emphasizes how mill culture was carried into the community, he does not differentiate between "steelworker consciousness" and "class consciousness" or ask how relevant the experience of steel towns is for more variegated working-class communities.

Even for steel towns, Bruno portrays an unbelievably isolated occupational culture, where steelworkers hardly ever interacted with people of other occupations. The vast majority of adult males in Struthers, after all, were not steelworkers. Many were probably in the Steelworkers' union, working in fabricating plants or suppliers not covered by the Basic Steel ("Cadillac") contract an important division in most steel towns, particularly by the 1970 s. There must also have been firefighters and cops, construction workers and postal workers, not to mention female-dominated occupations like teachers, nurses, secretaries and retail clerks. And, were there no small business owners of taverns, grocery stores and funeral homes who often played leadership roles in other blue-collar communities? Likewise, though black and Hispanic steelworkers made up 23 percent of the steel labour force in Youngstown (and of Bruno's interviews), their struggles both in the workplace and the community do not complicate Bruno's analysis.

Working-class consciousness is not the same as an occupational identity. It is about a dizzying variety of wage workers seeing a common interest among themselves, sharing a common vision of their position in society, and acting collectively to advance that interest and vision. It is about steelworkers, for example, identifying themselves with clerical workers who have much safer, more pleasant working conditions but also much lower pay. Bruno provides no assessment of this kind of classconsciousness among his Youngstown steelworkers.

This is a major flaw in a book with Alley's ambitions, but it should not overshadow the insightful portrait of workingclass culture Bruno develops. Other workers, even those who wear white or pink collars, will recognize many of their own habits of heart and mind in Bruno's plain-spoken appreciation of what it means to be working class.

JaCk Metzgar Roosevelt University 